\title{
Mutagenicity of the Extract from Defatted Rice Bran by Subcritical Water Treatment
}

\author{
Jintana WIBOONSIRIKUL ${ }^{1}$, Yukihiro SAKAI ${ }^{2}$, Asao HOSODA ${ }^{2}$, Hisahiro MORITA ${ }^{3}$, \\ Yukitaka KIMURA $^{1}$, Hisaji TANIGUCHI ${ }^{2}$, Takuo TSUNO ${ }^{3}$, and Shuji ADACHI ${ }^{1,}$ \\ ${ }^{1}$ Division of Food Science and Biotechnology, Graduate School of Agriculture, Kyoto University, \\ Sakyo-ku, Kyoto 606-8502, Japan \\ ${ }^{2}$ Industrial Technology Center of Wakayama Prefecture, 60 Ogura, Wakayama 649-6261, Japan \\ ${ }^{3}$ Tsuno Food Industrial Co., Ltd., 94 Shinden, Katsuragi-cho, Ito-gun, Wakayama 649-7194, Japan
}

\begin{abstract}
The mutagenicity of the extracts from defatted rice bran by water or subcritical water treatment at $50^{\circ} \mathrm{C}$ to $250^{\circ} \mathrm{C}$ was examined using the Umulac AT test, which is a kit reagent for assaying the genotoxin-induced $u m u$ gene expression. The examination revealed that the extract at any temperature was negative for the mutagenicity for both the $-\mathrm{S} 9$ and $+\mathrm{S} 9$ tests, which assess the mutagenicity of the sample itself and its metabolites, respectively.
\end{abstract}

Key words: Mutagenicity, defatted rice bran, subcritical water, Umulac AT test, $u m u$-test

\section{Introduction}

Rice bran is produced during the rice polishing process. Because the bran contains lipids, rice bran oil is extracted from it to yield the defatted bran as a by-product. The defatted rice bran is partly used as a feed, but is mostly discarded even though it still contains many useful components such as saccharides, proteins, and phenolic compounds.

Water that maintains its liquid state in the temperature range of $100^{\circ} \mathrm{C}$ to $374^{\circ} \mathrm{C}$ under pressurized conditions is called subcritical water or compressed hot water. This water has two distinct features compared to ambient water. One is a low relative dielectric constant, and the other is a high ion product. Because the former feature is similar to that of an organic solvent, the extraction of useful compounds from natural resources or agricultural by-products by the water has been reported [1-3]. The latter feature indicates that the concentrations of hydrogen and hydroxyl ions are high and that the water would act as an acid or base catalyst. The hydrolysis and degradation of saccharides [4-7] and fatty acid esters and fatty acids $[8,9]$ have been reported as well as the isomerization of a fatty acid [10] and hexoses [11].

Defatted rice bran contains saccharides and proteins.

(Received 16 Jan. 2008: accepted 10 Feb. 2008)

† Fax:+81-75-753-6285, E-mail: adachi@kais.kyoto-u.ac.jp
Phenolic compounds, such as ferulic acid, also exist in the free or bound form in the rice bran. Therefore, it is expected that the treatment of the defatted rice bran by the subcritical water produces useful or functional substances. We have reported the subcritical water treatment of defatted rice bran [12,13] and that the extracts have antioxidative, emulsifying and emulsion-stabilizing abilities. The extracts at $180^{\circ} \mathrm{C}$ or higher temperatures appeared brownish due to browning or the Maillard reaction. Because the discoloration indicates that compounds, which were originally not contained in the bran, are produced during the treatment, their mutagenicity is a concern and its examination is inevitable for use in food. It has been confirmed that the extract from defatted rice bran by ambient water has an antigenotoxic activity [14]. However, the extract by subcritical water has not yet been examined.

In this context, we examined the mutagenicity of the extracts from defatted rice bran by subcritical water treatment at various temperatures using an assay system for the genotoxin-induced umu gene expression [15].

\section{Materials and Methods}

\subsection{Materials}

Defatted rice bran $(1.5 \mathrm{~g})$ and distilled water $(75 \mathrm{~mL})$ were placed in a vessel made from SUS-316 stainless steel (Taiatsu Techno Corporation, Osaka, Japan). The vessel was tightly sealed and connected to mantle heater, the 
temperature of which was kept at 50,100,150, 200 or $250^{\circ} \mathrm{C}$. The temperature of the sample was monitored using a thermocouple installed in the vessel. After the mixture in the vessel was kept for 5 min at the desired temperature in a 17-A oven (Shimadzu, Kyoto, Japan), the vessel was transferred to an ice bath for cooling to ambient temperature. The bran extract was clarified by centrifugation and through a $0.45 \mu \mathrm{m}$ cellulose acetate membrane filter (Dismic-25CS, Advandec, Tokyo, Japan). The filtrate was then lyophilized to yield the extract in the solid state.

Umulac AT, which is a kit reagent for the $u m u$-test, was purchased from Jimro, Takasaki, Gunma, Japan. The kit reagent uses 2-(2-furyl)-3-(5-nitro-2-furyl)acrylamide (abbreviated $\mathrm{AF}-2$ ) and 2-aminoanthracene (2-AA), which have been confirmed to exhibit the mutagenicity, as positive controls for the $-\mathrm{S} 9$ and $+\mathrm{S} 9$ tests, respectively. S9 is the lyophilized homogenate of the rat liver, and converts a test compound into its metabolites. Therefore, the mutagenicity of the metabolites can be assessed in the $+\mathrm{S} 9$ test.

\subsection{Mutagenicity test}

An extract was dissolved in $10 \%$ dimethyl sulfoxide at a concentration of $10 \mathrm{mg} / \mathrm{mL}$. The solution was diluted every 10 times to $0.01 \mu \mathrm{g} / \mathrm{mL}$. The diluted sample solutions (10 $\mu \mathrm{L}$ each) were put on a microplate with 96 wells, and assayed using the Umulac AT kit according to the manufacturer's instruction. The mutagenicity was estimated by measuring the absorbance at $620 \mathrm{~nm}$. When the absorbance for a sample was twice as high as that for the solvent, the sample was judged to exhibit the mutagenicity.

As shown later, the above test indicated that the concentration on the order of $\mathrm{mg} / \mathrm{mL}$ was adequate for a more precise examination of the mutagenicity for all the samples. Therefore, the mutagenicity test was carried out in the concentration range of 0.5 to $20 \mathrm{mg} / \mathrm{mL}$ for all the samples using the Umulac AT kit.

\section{Results and Discussion}

\subsection{Determination of adequate sample concentration}

Table 1 shows the absorbance for the samples at the concentrations of $0.01 \mu \mathrm{g} / \mathrm{mL}$ to $10 \mathrm{mg} / \mathrm{mL}$ in the $-\mathrm{S} 9$ and $+\mathrm{S} 9$ tests. Although all five samples showed an absorbance higher than the solvent reference in the $+\mathrm{S} 9$ test at $10 \mathrm{mg} / \mathrm{mL}$, their mutagenicity was not estimated to be positive because the ratio of the absorbance of the sample to the reference was lower than 2 . These results indicated that the examination of the mutagenicity at the concentrations on the order of $\mathrm{mg} / \mathrm{mL}$ was favorable for all the samples.

\subsection{Mutagenicity of extract from defatted rice bran}

The solutions of 0.5 to $20 \mathrm{mg} / \mathrm{mL}$ were prepared for all

Table 1 Absorbance at $620 \mathrm{~nm}$ in the tests for determining adequate concentrations

\begin{tabular}{|c|c|c|c|c|c|c|c|c|c|c|c|c|c|c|}
\hline & \multirow{2}{*}{$\begin{array}{l}\text { Positive } \\
\text { control }\end{array}$} & & \multicolumn{2}{|c|}{ Extract at $50^{\circ} \mathrm{C}$} & \multicolumn{2}{|c|}{ Extract at $100^{\circ} \mathrm{C}$} & \multicolumn{2}{|c|}{ Extract at $150^{\circ} \mathrm{C}$} & \multicolumn{2}{|c|}{ Extract at $200^{\circ} \mathrm{C}$} & \multicolumn{2}{|c|}{ Extract at $250^{\circ} \mathrm{C}$} & \multirow{3}{*}{$\begin{array}{c}\text { Concentration } \\
\text { of extract } \\
{[\mu \mathrm{g} / \mathrm{mL}]}\end{array}$} \\
\hline & & & & $-\mathrm{S} 9$ & +S9 & $-\mathrm{S} 9$ & +S9 & $-\mathrm{S} 9$ & +S9 & $-\mathrm{S} 9$ & +S9 & $-S 9$ & +S9 & \\
\hline & & 1 & 2 & 3 & 4 & 5 & 6 & 7 & 8 & 9 & 10 & 11 & 12 & \\
\hline \multirow{4}{*}{$\mathrm{AF}-2$} & A & $\begin{array}{l}1.020 \\
\left(0.3^{* 1}\right)\end{array}$ & & 0.291 & 0.447 & 0.243 & 0.393 & 0.290 & 0.539 & 0.299 & 0.534 & 0.323 & 0.471 & 10000 \\
\hline & B & $\begin{array}{l}0.526 \\
\left(0.1^{* 1}\right)\end{array}$ & & 0.276 & 0.318 & 0.170 & 0.313 & 0.185 & 0.358 & 0.216 & 0.357 & 0.258 & 0.442 & 1000 \\
\hline & $\mathrm{C}$ & $\begin{array}{c}0.485 \\
\left(0.033^{* 1}\right)\end{array}$ & & 0.327 & 0.296 & 0.182 & 0.305 & 0.175 & 0.298 & 0.178 & 0.338 & 0.203 & 0.377 & 100 \\
\hline & $\mathrm{D}$ & $\begin{array}{c}0.259 \\
\left(0^{* 1}\right)\end{array}$ & & 0.255 & 0.322 & 0.172 & 0.314 & 0.172 & 0.319 & 0.184 & 0.323 & 0.172 & 0.364 & 10 \\
\hline \multirow{4}{*}{$2-\mathrm{AA}$} & $\mathrm{E}$ & $\begin{array}{l}1.574 \\
\left(0.3^{* 2}\right)\end{array}$ & & 0.188 & 0.315 & 0.192 & 0.320 & 0.181 & 0.333 & 0.191 & 0.321 & 0.189 & 0.361 & 1 \\
\hline & $\mathrm{F}$ & $\begin{array}{c}1.346 \\
\left(0.03^{* 2}\right)\end{array}$ & & 0.197 & 0.323 & 0.193 & 0.315 & 0.194 & 0.327 & 0.211 & 0.327 & 0.200 & 0.353 & 0.1 \\
\hline & G & $\begin{array}{c}1.005 \\
\left(0.003^{* 2}\right)\end{array}$ & & 0.201 & 0.318 & 0.199 & 0.312 & 0.191 & 0.340 & 0.206 & 0.330 & 0.198 & 0.362 & 0.01 \\
\hline & $\mathrm{H}$ & $\begin{array}{c}0.361 \\
\left(0^{* 2}\right)\end{array}$ & & 0.207 & 0.329 & 0.201 & 0.318 & 0.197 & 0.336 & 0.222 & 0.334 & 0.207 & 0.356 & $\begin{array}{l}\text { Solvent } \\
\text { control }\end{array}$ \\
\hline
\end{tabular}

*1 The concentration in units of $\mu \mathrm{g} / \mathrm{mL}$ of AF- 2 as a positive control for the $-\mathrm{S} 9$ test.

*2 The concentration in units of $\mu \mathrm{g} / \mathrm{mL}$ of $2-\mathrm{AA}$ as a positive control for the $+\mathrm{S} 9$ test. 
Table 2 Absorbance at $620 \mathrm{~nm}$ in the tests for the examination of mutagenicity of the extracts from defatted rice bran.

\begin{tabular}{|c|c|c|c|c|c|c|c|c|c|c|c|c|c|c|}
\hline & \multirow{2}{*}{$\begin{array}{l}\text { Positive } \\
\text { control }\end{array}$} & \multirow{2}{*}{$\begin{array}{c}\text { Negative } \\
\text { control }\end{array}$} & \multicolumn{2}{|c|}{ Extract at $50^{\circ} \mathrm{C}$} & \multicolumn{2}{|c|}{ Extract at $100^{\circ} \mathrm{C}$} & \multicolumn{2}{|c|}{ Extract at $150^{\circ} \mathrm{C}$} & \multicolumn{2}{|c|}{ Extract at $200^{\circ} \mathrm{C}$} & \multicolumn{2}{|c|}{ Extract at $250^{\circ} \mathrm{C}$} & \multirow{3}{*}{$\begin{array}{c}\text { Concentration } \\
\text { of extract } \\
{[\mathrm{mg} / \mathrm{mL}]}\end{array}$} \\
\hline & & & & $-\mathrm{S} 9$ & +S9 & $-\mathrm{S} 9$ & $+\mathrm{S} 9$ & $-\mathrm{S} 9$ & $+\mathrm{S} 9$ & $-\mathrm{S} 9$ & $+\mathrm{S} 9$ & $-\mathrm{S} 9$ & $+\mathrm{S} 9$ & \\
\hline & & 1 & 2 & 3 & 4 & 5 & 6 & 7 & 8 & 9 & 10 & 11 & 12 & \\
\hline \multirow{4}{*}{$\mathrm{AF}-2$} & A & $\begin{array}{l}1.719 \\
\left(0.3^{* 1}\right)\end{array}$ & 0.040 & 0.243 & 0.342 & 0.309 & 0.364 & 0.261 & 0.304 & 0.250 & 0.267 & 0.183 & 0.220 & 20 \\
\hline & B & $\begin{array}{l}0.957 \\
\left(0.1^{* 1}\right)\end{array}$ & 0.040 & 0.233 & 0.315 & 0.260 & 0.439 & 0.245 & 0.409 & 0.254 & 0.304 & 0.226 & 0.245 & 10 \\
\hline & $\mathrm{C}$ & $\begin{array}{c}0.547 \\
\left(0.033^{* 1}\right)\end{array}$ & 0.043 & 0.220 & 0.268 & 0.226 & 0.259 & 0.229 & 0.303 & 0.242 & 0.400 & 0.240 & 0.287 & 5 \\
\hline & $\mathrm{D}$ & $\begin{array}{c}0.209 \\
\left(0^{* 1}\right)\end{array}$ & 0.057 & 0.208 & 0.249 & 0.207 & 0.239 & 0.226 & 0.279 & 0.239 & 0.392 & 0.238 & 0.324 & 2.5 \\
\hline \multirow{4}{*}{$2-\mathrm{AA}$} & $\mathrm{E}$ & $\begin{array}{l}1.600 \\
\left(0.3^{* 2}\right)\end{array}$ & 0.061 & 0.212 & 0.221 & 0.207 & 0.228 & 0.214 & 0.233 & 0.228 & 0.266 & 0.241 & 0.335 & 1 \\
\hline & $\mathrm{F}$ & $\begin{array}{c}0.770 \\
\left(0.03^{* 2}\right)\end{array}$ & $\begin{array}{c}0.036 \\
\text { (empty }^{* 3}\end{array}$ & 0.203 & 0.216 & 0.199 & 0.221 & 0.214 & 0.234 & 0.214 & 0.245 & 0.220 & 0.313 & 0.5 \\
\hline & G & $\begin{array}{c}0.326 \\
\left(0.003^{* 2}\right)\end{array}$ & $\begin{array}{c}0.036 \\
\text { (empty }^{* 3}\end{array}$ & 0.039 & 0.039 & 0.042 & 0.040 & 0.042 & 0.042 & 0.050 & 0.050 & 0.056 & 0.055 & 10 \\
\hline & $\mathrm{H}$ & $\begin{array}{c}0.233 \\
\left(0^{* 2}\right)\end{array}$ & $\begin{array}{c}0.036 \\
\text { (empty }^{* 3}\end{array}$ & 0.224 & 0.229 & 0.221 & 0.227 & 0.218 & 0.211 & 0.212 & 0.254 & 0.219 & 0.255 & $\begin{array}{l}\text { (No microbial) } \\
\text { Solvent control }\end{array}$ \\
\hline
\end{tabular}

* 1 The concentration in units of $\mu \mathrm{g} / \mathrm{mL}$ of $\mathrm{AF}-2$ as a positive control for the $-\mathrm{S} 9$ test.

${ }^{*} 2$ The concentration in units of $\mu \mathrm{g} / \mathrm{mL}$ of $2-\mathrm{AA}$ as a positive control for the $+\mathrm{S} 9$ test.

*3 The wells contained no solution.

the samples to use in the Umulac AT test (Table 2). Some extracts showed the absorbance about twice the absorbance of the solvent reference in the $+\mathrm{S} 9$ test. The values in column 2 and in row $\mathrm{G}$ are the absorbance for the 20 $\mathrm{mg} / \mathrm{mL}$ and $10 \mathrm{mg} / \mathrm{mL}$ samples, respectively, which were diluted with sterilized water instead of the culture solutions as negative control, and they were in the range of 0.039 to 0.061 . The absorbance of the empty wells (F2, G2 and H2) also showed the absorbance of 0.036 . Therefore, the brownish color would not interfere with the assay, and no sample exhibited the absorbance twice as high as that of the reference.

In conclusion, all the extracts from the defatted rice bran at $50^{\circ} \mathrm{C}$ to $250^{\circ} \mathrm{C}$ by water or subcritical water treatment have a negative mutagenicity based on the rapid determination by the Umulac AT test.

Amino group in protein or amino acid is often converted to nitro or azoxy group, which has a high mutagenicity, by treatment at high temperatures. However, the extracts obtained from defatted rice bran by its subcritical water treatment exhibited no mutagenicity. The reason for this fact remains unclear. A possible explanation might be a relatively low protein content of the defatted rice bran and no conversion of amino group to harmful ones during the treatment.

\section{Acknowledgments}

This study was financially supported by the Cooperation for Innovative Technology and Advanced Research in Evolutional Area (CITY AREA) program by the Ministry of Education, Culture, Sports, Science and Technology, Japan. One of the authors (JW) acknowledges the Monbukagakusho Scholarship from the Japanese Government.

\section{References}

[1] T. M. Pawlowski, C. F. Poole; Extraction of thiabendazole and carbendazin from foods using pressurized hot (subcritical) waster for extraction: a feasibility study. J. Agric. Food Chem., 46, 3124-3132 (1998).

[2] R. S. Ayala, L. Castro; Continuous subcritical water extraction as a useful tool for isolation of edible essential oils. Food Chem., 75, 109-113 (2001).

[3] M. H. Eikani, F. Golmohammad, S. Rowshanzamir; Subcritical water extraction of essential oils from coriander seeds (Coriandrum sativum L.). J. Food Eng., 80, 735-740 (2007).

[4] M. Sasaki, Z. Fang, Y. Fukushima, T. Adschiri, K. Arai; Dissolution and hydrolysis of cellulose in subcritical and supercritical water. Ind. Eng. Chem. Res., 39, 2883-2890 (2000). 
[5] Y. Sun, J. Cheng; Hydrolysis of lignocellulosic materials for ethanol production. Bioresour. Technol., 83, 1-11 (2002).

[6] T. Oomori, S. Haghighat Khajavi, Y. Kimura, S. Adachi, R. Matsuno; Hydrolysis of disaccharides containing glucose residue in subcritical water. Biochem. Eng. J., 18, 143-147 (2004).

[7] S. Haghighat Khajavi, Y. Kimura, T. Oomori, R. Matsuno, S. Adachi; Degradation kinetics of monosaccharides in subcritical water. J. Food Eng., 68, 309-313 (2005).

[8] P. Khuwijitjaru, T. Fujii, S. Adachi, Y. Kimura, R. Matsuno; Kinetics on the hydrolysis of fatty acid esters in subcritical water. Chem. Eng. J., 99, 1-4 (2004).

[9] T. Fujii, P. Khuwijitjaru, Y. Kimura, S. Adachi; Decomposition kinetics of monoacyl glycerol and fatty acid in subcritical water under temperature-programmed heating conditions. Food Chem., 94, 341-347 (2006).

[10] C. Usuki, Y. Kimura, S. Adachi; Conversion of linoleic acid to its conjugated isomers in subcritical water. Japan J. Food Eng., 7, 147-150 (2006).

[11] C. Usuki, Y. Kimura, S. Adachi; Isomerization of hexoses in subcritical water. Food Sci. Technol. Res., 13, 205-209 (2007).

[12] J. Wiboonsirikul, Y. Kimura, M. Kadota, H. Morita, T. Tsuno, S. Adachi; Properties of extracts from defatted rice bran by its subcritical water treatment. J. Agric. Food Chem., 55, 8759-8765 (2007).

[13] J. Wiboonsirikul, P. Khuwijitjaru, Y. Kimura, H. Morita, T. Tsuno, S. Adachi; Production optimization of the extract with high phenolic content and radical scavenging activity from defatted rice bran by subcritical water treatment. Japan J. Food. Eng., 8, 311-315 (2007).

[14] K. Higashi-Okai, K. Kanbara, K. Amano, A. Hagiwara, C. Sugita, N. Matsumoto, Y. Okai; Potent antioxidative and antigenotoxic activity in aqueous extract of Japanese rice bran -association with peroxidase activity. Phytother. Res., 18, 628-633 (2004).

[15] G. Reifferscheid, J. Heil, Y. Oda, R. K. Zahn; A microplate version of SOS/umu-test for rapid detection of genotoxins and genotoxic potentials of environmental samples. Mutation Res., 253, 215-222 (1991). 